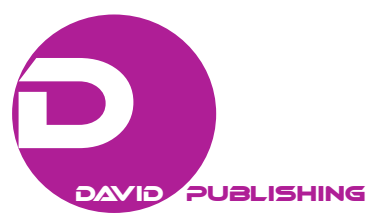

\title{
Aligning Europe: The Syrian Refugee Crisis and the Geopolitics of the Region
}

\author{
Sotiris Serbos \\ Democritus University of Thrace, Komotini, Greece \\ Christos Baxevanis \\ University of Macedonia, Thessaloniki, Greece
}

\begin{abstract}
This article examines the Syrian refugee crisis as a case study in order to understand how foreign policy practices developed by the US in the Middle East and Europe's refugee policy for handling mass influxes are interconnected. With international politics evolving in a dynamic and not static manner, the authors note that the conflicts driving today's refugee crisis are symptomatic of the shifting structure of international system that has been developed over the past 70 years with the emphasis being placed on the regional realities and the geopolitical competitions in the Middle East. In this respect, the authors provide an overview of the changing nature of the foreign policy strategy of the US in a globalizing multi-polar world and its linkage with migration movements in the Middle East. By acknowledging and taking advantage of one of the oldest and most enduring concepts of international relations, the authors outline the dynamics of the balance of power strategy in an emerging multi-polar world and describe the prudent pursuit of an "offshore balancing" grand strategy by the US and firmly consistent with America's global interests. By bringing forward a framework analysis which recognizes the soaring refugee and migration flows as the spillover effect of the US sponsored "offshore balancing" regional strategy for setting the principles and paving the way towards gradually establishing a functional balance of power in the Middle East, the authors draw special attention to the influential role of the EU and its incomplete attempt, via the refugee crisis, to adjust to the US's grand strategy which allows for fairer shifting of global burdens and security threats with profound repercussions on regional and international stability.
\end{abstract}

Keywords: Syrian refugees, offshore balancing, US foreign policy, Turkey, EU

\section{Methodology and Theoretical Assumptions}

In order to make sense of the contemporary international system with a focus on the geopolitics of the Middle East, the grand strategy pursued by the US and the implications on forced displacement in Syria, the authors bring forward a set of analytical tools from the international relations theory offered by the works of leading structural realists (American political scientists Christopher Layne and Stephen Walt). "Grand strategy is an important-sounding term but the concept is simple: it is the process by which a state matches ends and means in the pursuit of security" (Layne, 1998, p. 8). According to Schwartz and Layne (2002), "great powers have two basic strategic options: they can pursue geopolitical dominance (a 'uni-polar' strategy), or they can

Sotiris Serbos, Assistant Professor, School of Social, Economic and Political Sciences, Democritus University of Thrace.

Christos Baxevanis, Postdoctoral fellow, Department of Balkan, Slavic \& Oriental Studies, University of Macedonia. 
seek to maintain a rough balance of power among the strongest states in a region or around the world (a 'multi-polar' strategy)" (p. 36). Noting both the role and the limitations of the US for managing global security and matching shifting regional power relationships but also the desire of emerging regional powers to gain more authority and leadership within the present liberal international order, the authors adhere to the guideline that "the United States can best obtain security by taking advantage of the dynamics of the balance of power in an emerging multi-polar world" (Layne, 1998, p. 20).

On this matter, "offshore balancing" is a 21 st century balance of power grand strategy which aims to maximize America's strategic flexibility and its relative power position so as to continue engaging itself as the leading power within the liberal international order. "So for an offshore balancing strategy to work, the world must be multi-polar, that is, there must be several other great powers, and major regional powers as well, onto which the United States can shift the burden of maintaining stability in various parts of the world" (Schwartz \& Layne, 2002, p. 40). As Walt (2011) vividly describes,

Offshore balancing seeks to maintain benevolent hegemony in the Western Hemisphere and to maintain a balance of power among the strong states of Eurasia and of the oil-rich Persian Gulf [...] Instead of seeking to dominate these regions directly, however, our first recourse should be to have local allies uphold the balance of power, out of their own self-interest. Rather than letting them free ride on us, we should free ride on them as much as we can, intervening with ground and air forces only when a single power threatens to dominate some critical region. For an offshore balancer, the greatest success lies in getting somebody else to handle some pesky problem, not in eagerly shouldering that burden oneself. (p. 13)

In this regard, building on the conceptual framework of Layne and Walt and applying it to the region of the Middle East, the aim of the article is to link the Syrian migration crisis to the overall changing nature of the foreign policy strategy of the US in a globalizing multi-polar world. Thereby, answering the main research question and provide a root cause analysis for understanding the recent mass refugee flows from Syria towards Europe. As a result of the progressive shift of America's foreign and defense policy priorities from the region of Middle East to the one of Asia-Pacific, Washington's game-changing for managing Middle East's regional rivalries and hard-security threats is inextricably linked to the successful coordination of a set of alliances in a far from straightforward security environment. Most importantly, "offshore balancing prescribes a very different approach to the greater Middle East" (Walt, 2011, p. 14) since it includes America's military disengagement from the region and its reliance on local Middle Eastern allies to maintain the peace-with the US offering its help when necessary (Walt, 2011, p. 15).

The authors' analysis includes America's current grand strategy and the foreign policy practices developed both by the US and key rising powers' intraregional rivalries (Turkey, Iran) in the Middle East's regional context. In addition, when it comes to Europe, the migration crisis is evaluated as a case study for assessing the role of the EU and the pitfalls involved for being able to effectively make the transition and adjust itself to the US's offshore balancing strategy which allows for burden shifting, rather than burden sharing. As such, at a time when greater cohesion and activism are needed to adequately respond to America's burden shifting approach, Europe's unfinished business should not be put on hold, including an alignment of the EU's internal and external policies as never before. When it comes to the added value of the topics discussed, while "policy makers pay relatively little attention to the vast theoretical literature in IR, and many scholars seem uninterested in doing policy-relevant work" (Walt, 2005, p. 23), the paper's possible contribution can be viewed as an attempt to place greater value on policy-relevant theoretical work regarding America's offshore balancing 
strategy in the greater Middle East and its impact on Syria's refugee crisis.

\section{Introduction}

The unprecedented level of global forced displacement of wars and conflicts in Syria, Iraq, Afghanistan and sub-Saharan Africa, coupled with the rapidly deteriorating insecurity in Libya and closed land routes for mixed migratory flows in other regions, have triggered a sharp increase in the number of refugees. The number of immigrants and refugees who crossed Europe's borders in 2015 is quadruple compared with the one of 2014 (Frontex, 2015). The total number of immigrants and refugees who reached Europe by land and sea was 280,000 in 2014, while in 2015, it is estimated that one million people arrived in Europe. The majority of immigrants and refugees came from the Mediterranean, with more than 800,000 people crossing the Aegean to reach Greek shores from Turkey (BBC, 2016). According to the International Organization for migration, 13 times more people have crossed the Mediterranean Sea in January 2016 compared to those of January 2015, while 368 people died during just the first month of 2016 (IOM, 2016). The tragedy occurred off the coast of the Italian island of Lampedusa on the 3rd of October 2013, where 350 people died at sea, marked the Mediterranean as the deadliest sea crossing (European Council on Refugees and Exiles, 2014).

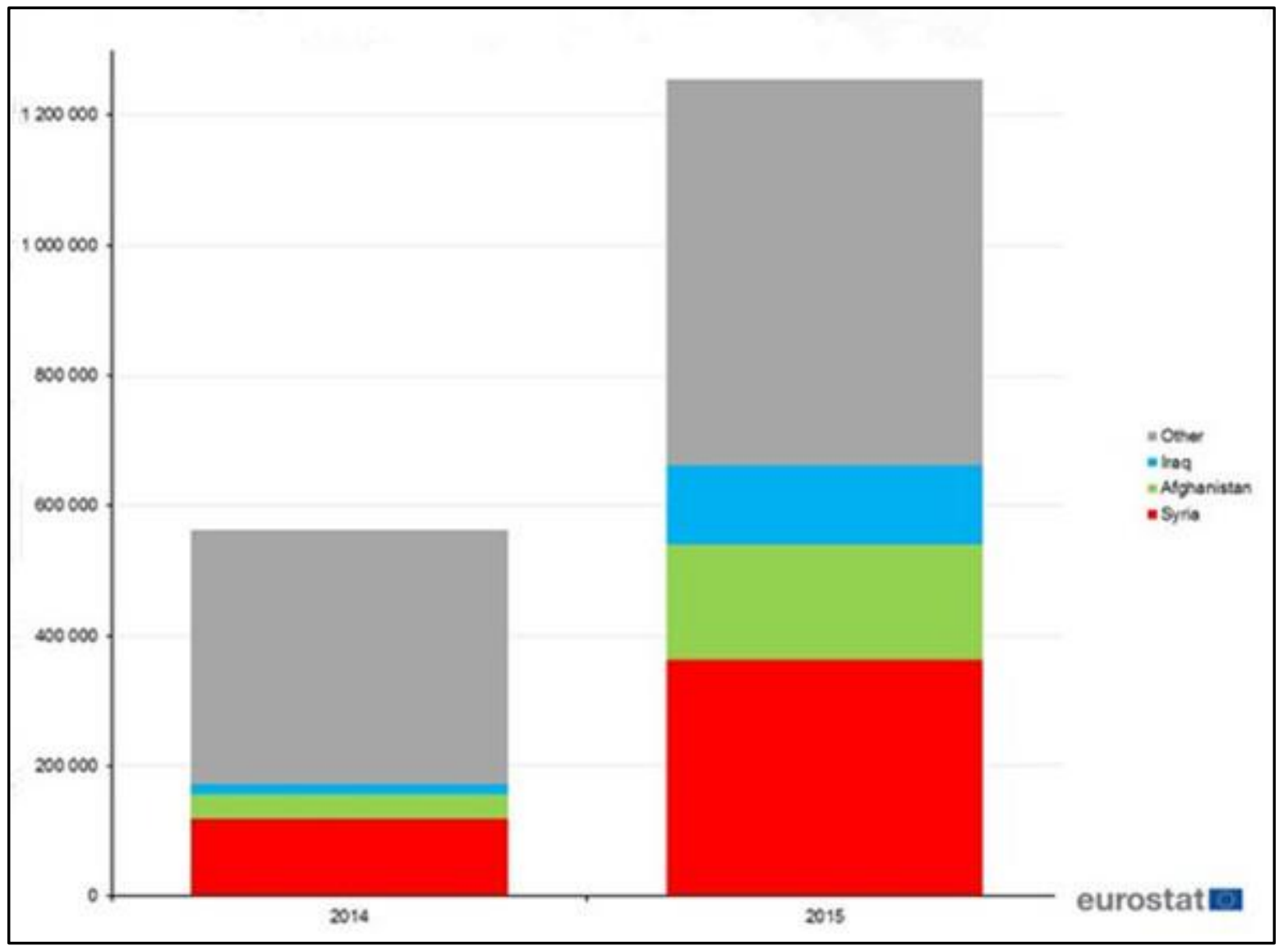

Figure 1. First time asylum applicants registered in the EU Member States.

In 2013, Syria for the first time became the main country of origin of asylum-seekers in 44 industrialized countries in Europe, North America, and the Asia Pacific region. Germany, Sweden, the United Kingdom and the United States of America are among the top five states receiving asylum claims (UNHCR, 2014). By the 
end of 2015, according to the European Asylum System Office (EASO) Annual Report on the Situation of Asylum in the EU, EU countries recorded 1,349,638 asylum applications. This is more than twice the level recorded in 2014 and the highest annual number of asylum applications in the EU since EU-wide data collection started in 2008. Syria was the top citizenship of applicants reported followed by Afghanistan and Iraq.

The main receiving countries were Germany, Sweden, Italy, France and Hungary. Germany has received the greatest number of asylum application over the last years. It is worth mentioning that Germany received 41,100 Syrian asylum applications in 2014 alone, over three-fold the number filled in 2013, and five times the number received in 2012 (Ostrand, 2015).The latest figures available for 2016 indicate that the number of applications for international protection continues to rise. After three months of consecutive decrease, February saw an $11 \%$ increase compared to January. Syria remained, for the 10th consecutive month, the top citizenship followed by Iraq which came in second place displacing Afghanistan which fell to third place. With the fights raging in Syria and Iraq, minorities in Afghanistan being suppressed, and the extreme poverty in North and East Africa, the number of refugees and immigrants is not expected to diminish this year, either. On the contrary, the European Commission expects 1.5 million in 2016 and 500,000 in 2017 to enter Europe via the Eastern Mediterranean and the Balkans (BBC, 2015).

\section{Europe's Response to the Syrian Refugee Crisis}

At EU level, the massive arrival of refugees, mainly from Syria, and immigrants without legal documents by different countries, strongly affects European societies, as well as the internal political situation in almost all member-states of the EU, putting to the test the Schengen Treaty and the Dublin rules and highlighting the limits, the deficiencies and the interplay between the policies pursued at both the European and the national level of its member-states.

\section{The EU's Asylum and Migration Policy}

Since 1999, the EU has been committed to establish a Common European Asylum System (CEAS) and improve its current framework. The EU's migration and asylum policy builds on European legislation and legal instruments, political instruments, operational support and capacity-building, and the wide range of program and project support that is made available to numerous stakeholders, including civil society, migrant associations and international organizations. Over the last three decades, harmonization towards the common EU migration and asylum policy has become one of the most important issues of European integration (Baxevanis \& Papadaki, 2014, pp. 112-116). New EU rules have now been agreed (The Revised Asylum Procedures Directive, The Revised Reception Conditions Directive, The Revised Qualification Directive, The Revised Dublin Regulation and The Revised Eurodac), setting out common high standards and stronger co-operation to ensure that asylum seekers are treated equally in an open and fair system.

\section{From the European Agenda on Migration}

In 2015, the international community was alarmed by the plights of thousands of refugees putting their lives at risk to enter the EU. The migration crisis in the Mediterranean has put a spotlight on their immediate needs. By the same token, it has also revealed much about the more systemic and structural constraints of EU's migration policy and the tools at its disposal. 
The October 2013 Lampedusa tragedy pushed EU leaders to react. The Task Force Mediterranean was the first attempt to respond followed by the Triton operation that was meant to replace Mare Nostrum. The European agenda for migration, as of May 2015, was the 3rd EU response to the plight of thousands of immigrants, introducing for the first time in the Union's glossary terms such as relocation and resettlement. ${ }^{1}$ Through this agenda EU aims at setting out a comprehensive approach to migration management. It is worth mentioning that, in its approach, migration, asylum, foreign policy and security constitute four interconnected axes. The agenda is built upon four main pillars: reducing the incentives irregular migration, saving lives and securing external borders, strengthening the common asylum policy as well as developing a new policy on legal migration. In September, member states agreed to relocate 160,000 people in need of international protection from those countries most affected on the base of a set formula-i.e. $40 \%$ of the size of population, $40 \%$ of the GDP, $10 \%$ of the average number of past asylum application and $10 \%$ of the unemployment rates. They have also agreed to resettle 22,000 refugees from camps outside the EU, and another development came in November 2015. The EU-Turkey Summit in Brussels was crucial for both the refugee crisis and Turkey's EU accession process. Towards this direction, an action plan was decided for managing the refugee crisis.

Terrorist attacks by the extremist organization ISIS/Daesh, which took place at the same time with the desperate effort of hundreds of thousands of refugees and migrants to reach European territory, confirmed in the worst possible way the concerns of the Heads of States and Governments, regarding the protection of EU's external borders. The bloody terrorist attacks in Paris produced a total recall from the strikes in New York, Washington, Madrid and London, and at the same time, they were perceived as the European equivalent of 9/11. The strong fear that the immigration flows could be manipulated by terrorist organizations, and particularly ISIS/Daesh, divides member states and is leading the EU towards an adjustment of its initial positions on immigration (Nomikos, 2013, pp. 288-303).

Since the fall of 2015, anumber of countries decided to temporarily reintroduce checks at the internal borders (Austria, Denmark, Germany, and Sweden). In November 2015, following the terrorist attacks in Paris, France was also added in the above group of countries. The most important initiative came from the Visegrad Group (also known as the "Visegrad Four" or simply "V4") including the Czech Republic, Hungary, Poland and Slovakia. By stressing their distinct national identities and the risks ahead for both their national sovereignty and internal security they decided to seal their borders and built fences for enhanced border protection. There is no doubt that "V4", together with Austria, have become the key opponent to Germany's policy of open borders and EU's common action. On the other hand, in order to properly manage irregular migration and protect refugees, member states need to be actively participate and share burdens. Thus, Germany cannot stand alone in this endeavor. At the same time, the rise of Eurosceptic and anti-European parties in several EU member-states (France, Poland, Sweden, Netherlands, Belgium, Austria, Denmark and Italy) with different ideological hues and largely contradictory views - but with a common denominator and a key sign of populism and xenophobia - cause great concern. The European debt crisis and the rapid increase of refugee and migration numbers have strengthened the centrifugal forces within the EU and continue destabilizing the European integration project as a whole (Lehne, 2016).

\footnotetext{
${ }^{1}$ European Union: European Commission, Communication from the Commission to the European Parliament, the Council, the European Economic and Social Committee and the Committee of the Regions. An European Agenda on Migration, 13 May 2015 , COM (2015) 240 final.
} 


\section{... to the EU-Turkey Refugee Deal}

The agreed plan of 18 March 2016 between Turkey and the EU has set forward Europe's ambitious goal to stop the refugee and migration flows from Turkey to Greece and prevent the collapse of the Schengen Area. The reality, however, is that the implementation of the agreement that began on April 4 2016, faces serious problems for a number of legal, political and logistical reasons, as it is an agreement characterized as highly complex and extremely technical (including a variety of controversial legal issues) (The Economist, 2016).

Turkey undertakes to take back all illegal entrants from Greece. It sounds impressive, but in all reality, it won't be, because only those who do not seek asylum will go back, while those who seek should be examined individually, and in case of rejection, will retain the right of appeal whatever this means about the duration of the process and also the obligation of the Greek State to ensure them a decent living. By extension, the promise that for every Syrian being returned to Turkey from Greek islands, another Syrian will be resettled from Turkey to the EU, will have limited practical use, because ultimately, only a few Syrians would choose to return. The rapid increase of asylum requests in Greece demonstrates the above prediction (Collet, 2016). It is worth mentioning that the weekend just before the start of the immigrant returns in Turkey, in the Greek island of Lesvos, approximately 3,000 submitted asylum applications. In addition, the maximum number of Syrian refugees who will be transported from Turkey in EU countries is 72,000, while the number of Syrian refugees is far bigger. The situation would be different if there was a massive resettlement program from Turkey, Jordan and Lebanon.

At the same time, there is no organized plan for the refugees and irregular migrants who are already within the Greek territory. Border closures along the Western Balkan route caused a bottleneck with more than 50,000 people being stranded in Greece and unable to continue their journey to Europe. Instead, the relocation of refugees in Europe is still voluntary and EU member-states decision to close the Balkan route still stands. Resettlement needs relocation and that is not working at all: Only a few hundred of refugees from Greece and Italy have been moved to other member states. The European Commission issued an update on the progress made up until the 11th of April 2016. Assessing the actions undertaken by EU's member states to implement the emergency relocation and European resettlement schemes, the report concluded that little progress has been made since mid-March. Only 208 additional persons have been relocated during the reporting period, bringing the total number of relocated applicants from Greece and Italy to 1,145 so far of the agreed 6,000 by 16 April, and 20,000 by the 16th of May. Regarding resettlement, 5,677 people have been resettled much less than the agreed $22,504 .^{2}$

Serious questions have also risen in terms of the agreement's legal aspects. First and foremost, to declare a country as a "safe third country", both International and European law set a series of preconditions, which Turkey has not been adequately fulfilling. Besides, Turkey would have to apply the Geneva Convention to all nationalities and not just to EU citizens as far as its current status is concerned (Oktav \& Çelikaksoy, 2015). It is worth mentioning that, in its report, Amnesty International refers to the repeated violations of the principle of non-refoulement from Turkey that happens through the daily expulsions of refugees in Syria (Amnesty International, 2016). In this context, taking into account the conflict between Turkey and the Syrian Kurds, it would be problematic to forcibly return to Turkey a member of this minority. Furthermore, the second

\footnotetext{
${ }^{2}$ European Union: European Commission, Communication from the Commission to the European Parliament, the European Council and the Council: Second Report on relocation and resettlement, 12 April 2016, COM (2016) 222 final.
} 
paragraph of the agreement, which refers to the "one in, one out" principle, is in direct contrast with the principle of refugee law, which does not allow selection criteria to be based on nationality. These concerns are reinforced by the fact that there is no plan for verification mechanism in order to check Turkey's compliance. All these issues, if placed before the European courts, are very likely to call into question the legal compatibility of the agreement with the International and European framework for the protection of refugees (Brooks, 2016).

Finally, the implementation of the agreement by the Greek side requires the mobilization of an immense bureaucratic mechanism (including judges, asylum experts, police officers and interpreters amongst others). In other words, Greece is invited to carry out an unprecedented administrative, legislative and operational project that has not been undertaken so far. A major obstacle in fulfilling these requests is the limited staff of the asylum service, especially on the Greek islands which serve as gateways to Europe, and the fact that Appeals Authority, the body which examines at second instance requests for international protection, is still expecting its reopening since September (Syrigos, 2016).

There is no doubt that, since the EU-Turkey Agreement, there has been a substantial decrease in the number of irregular migrants and asylum seekers crossing from Turkey into Greece. However, according to the first report on the progress made in the implementation of the EU-Turkey deal, only 325 persons have been returned from Greece to Turkey, and just 74 Syrians asylum seekers were resettled from Turkey to the EU. ${ }^{3}$ Additionally, even though the existing channels are now closed, there is always the danger of migration flows being re-routed: with the closing of the Western Balkans Route, the illegal networks of traffickers might seek an alternative route passing from Greece through Albania to the EU, going back through South Italy and/or finally going from Turkey through the Black Sea to Bulgaria (Euroactic.com, 2016).

\section{Syria's Refugee Crisis in the Context of the Middle East}

Since 2011, as a consequence of the Syrian conflict (the worst refugee crisis since World War II), tens of thousands innocent civilians have been killed and millions of people have been internally displaced or applied for asylum. In early September 2015, the UN announced that seven million had been internally displaced and more than four million had left the country, from a pre-war population of 22 million inhabitants. The neighboring countries of Turkey, Lebanon, Jordan, Iraq, and Egypt have received the largest numbers of refugees (Berti, 2016).

At the time of writing, Turkey continued hosting the largest Syrian population, with 2,749,140 registered refugees; Lebanon, a country facing major economic hurdles and of approximately 4.8 million people before the outcome of the Syrian refugee crisis, hosts 1,055,984 registered refugees; Jordan hosts the third largest population with 642,868 registered refugees. In comparison, Iraq and Egypt, host 246,123, and 119,665 registered refugees, respectively.

Undoubtedly, the refugee crisis relates to a variety of multi-level rivalries and conflicts in the Middle East and North Africa. Regarding the Middle East in particular, Syria's fragmented landscape has become the center stage of a "geopolitical laboratory" where major powers and regional actors confront one another in an effort to increase and/or maintain their distinct spheres of influence (US, Iran, Turkey, Russia, Saudi Arabia, ISIS/Daesh,

\footnotetext{
${ }^{3}$ European Union: European Commission, Communication from the Commission to the European Parliament, the European Council and the Council: First Report on the progress made in the implementation of the EU-Turkey Statement, 20 April 2016,COM(2016) 231 final.
} 
and the Syrian Kurds). Following the progressive shift of America's foreign and defense policy priorities from the Middle East region to the Asia-Pacific, the soaring refugee and migration flows are inextricably linked to the geopolitical regrouping that was needed for setting the principles and paving the way towards steadily establishing a functional balance of power strategy in the region sponsored by the US (see section II).

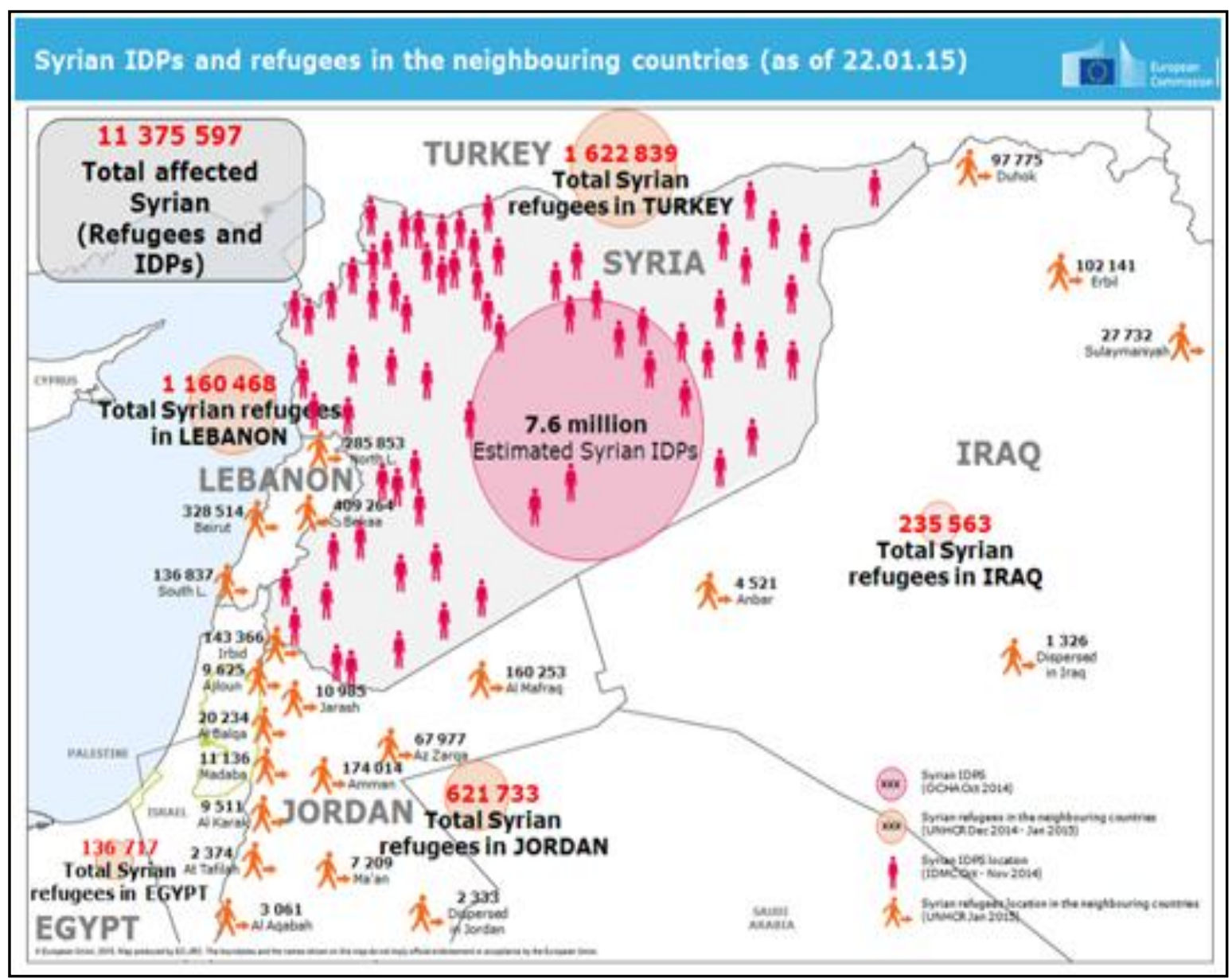

Figure 2. Syrian IDPS and refugees in the neighbouring countries (as of 22.01.15).

Following an absence of clarity and a consistent behavior on behalf of the world's powers, the terrorist organization ISIS/Daesh has taken advantage of the power vacuums in Syria and Iraq, thereby creating new realities in the Middle East and threatening to reshape the map of the region. At the same time, the brutal terrorist attacks in European countries (France, Belgium) confirmed the risk of extending this threat into the rest of the West. When it comes to the role of Europe, the refugee crisis has once again underlined the close link between the EU's global role and its ability to take swift decisions internally. Consequently, European action in the foreign policy domain will have to incorporate the need for expanding the perimeter of the Union's sphere of institutional cooperation and steadily developing a much more proactive, comprehensive and even forceful foreign policy for the Middle East and the North Africa. Germany's decisive approach in August 2015 to shift its policy and open the country's borders to the great refugee wave is a first step towards this direction. In close cooperation with the US administration, the decision of the German government has indicated Europe's political willingness to accept Washington's offshore balancing strategy for shifting global 
burdens and security threats with profound repercussions on regional and international stability. Unfortunately, the Germans did not succeed in ensuring the solidarity of the rest of their fellow EU member-states. Still, the Germans take more than credit in providing relief to the thorny displacement of Syrian refugees that washed over Europe in 2015. What is more, they have significantly contributed towards avoiding an evident expansion in militant identities over Syria and further fueling of Islamic extremism.

Last but not least, apart from the inadequate international response, one has to note the overall failure of the Arab world to progress according to the principles of democratic governance. With the exception of Tunisia, the Arab Spring has been disappointing. Egypt and Bahrain, regressed to a worse situation, Libya and Yemen are at the mercy of the fights between each other's clans, while Syria is on the brink of collapse, after five years of civil war. The Islamic countries of the Middle East, did not just fail to consolidate a democratic model of governance, but they are also in grave danger of returning to pre-modern forms of socio-economic and governance structures. In the end of the day, nothing will change in the Middle East as long as local actors fail to come to terms with the need for embracing a new regional narrative based on good governance and legitimacy. A narrative which will pave the way for a more interdependent and even integrated neighborhood would enlarge and cut across the modernist political space of nation-states.

\section{The Geopolitics of the Syrian Refugee Crisis}

\section{The Role of the US}

Historically, the United States has been developing, almost by default, a tactic of indirect engagement in global affairs and regional crises. However, from 1990 to 2008, the US has been using military power as the default for dealing with foreign issues, leading as the single superpower. From Panama to Somalia, Kosovo, Afghanistan and Iraq, US followed a policy of direct and early military involvement. This was not the case over the period 1914-1989, when the strategy was to provide political support to allies, followed by economic and military aid, which have included advisers and limited forces. The US kept its main force in reserve for circumstances in which (WWI, WWII, Korea, Vietnam) allies could not contain a new potential hegemon. At that time, the use of military force was perceived as the last resort. This was primarily a strategy of maintaining a global balance of power. The containment of the Soviet Union involved creating an alliance system, which incorporated countries at risk of Soviet attack. In this framework, containment was a balance of power strategy that did not seek the capitulation of the Soviet Union as much as increasing the risks of offensive action using allied countries as the first barrier. The threat of full US intervention and the potential of using nuclear weapons, put together with NATO's alliance structure, constrained Soviet risk-taking.

A review of the policies undertaken by the current US administration (2009-2016) suggests the return of the balance of power strategy and its adjustment in the modern global context where the US is making the transition and develops its offshore balancing strategy so as to maximize its strategic flexibility and its relative power position ${ }^{4}$. The shift of policy unveils the pressing reality which involves the desire of emerging regional powers to gain more authority and leadership within the liberal international order where the US will continue to engage itself as the leading power. In this respect, the role of the US for managing global security and matching shifting regional power relationships in a liberal economic order is increasingly linked to the Asia-Pacific region. The need for establishing a closer, more favorable and enduring geopolitical understanding

\footnotetext{
${ }^{4}$ The underlying premise of an offshore balancing strategy is that it will become increasingly more difficult, dangerous and costly for the United States to maintain order in, and control over, the international political system (Layne, 1998, p. 21).
} 
with China over regional security settings with global implications has been firmly recognized in Washington. By reducing its military presence in Europe and the Middle East, the US administration continues to pave the way for pivoting its strategic gaze to Asia with the aim of becoming the central broker in China's external relations (Niblett, 2012; Brooks, Ikenberry, \& Wohlforth, 2013, pp. 130-142). ${ }^{5}$ Through this strategy, Washington seeks to maintain its network of key alliances in the region, project its capacity for military intervention and above all avoid facing unfavorable trends in the Asian balance of power leading to "a less cooperative order built on spheres of influence" (Ikenberry, 2011).

\section{Rebalancing the Middle East}

As a result of the gradual process which has been described, America's foreign and defense policy priorities are shifting and the Middle East region steadily scores lower, compared to the past, as a valuable but still peripheral piece in the security puzzle of shaping Washington's grand new equilibrium strategy in Eurasia. However, pulling of resources for unfolding a solid and durable US strategic rebalancing to Asia is inextricably linked to successfully coordinate a set of alliances and to manage Middle East messy relations in a far from straightforward deteriorating security environment where "border conflicts, national ambitions, security fears, ethnic animosities and religious fanaticism" (Brookings Institution, 2012) forcefully coexist and persistently clash with each other. All in all, in an effort to achieve and maintain a functional balance of power by managing and stabilizing fragile relationships, a development allowing over time the US military presence there be kept to a minimum while the administration will continue leading from behind to defend its strategic interests in the region, which include: (1) securing the free flow of oil to global markets; (2) ensuring nuclear proliferation; (3) sustaining counter-terrorism efforts and reducing extremist violence. At that point, giving rise to, as Brzezinski notes, a period when the United States becomes more of a "balancer, influencer, but not direct participant in mainland conflicts" (Brookings Institution, 2012).

In order to avoid a dangerous escalation of the region's security dilemmas due to intensified competition, America's gradual disengagement from the Middle East goes hand in hand with the establishment of geopolitical arrangements between contrasting interests which the US - by acting as an "offshore balancer" via a coordination of alliances - succeeds to neutralize, establishing the so-called "neutral balancing". Thereby, creating a balance among competing interests that serves as a necessary prerequisite to provide room for neutralization of forces and space for allowing Washington's pull back from the region. Above all, it serves the interests of a medium term US strategy for establishing a well-ordered and resource-effective balance of power that leaves the region more secure. Needless to say that, the aforementioned strategy will progressively evolve rather than just happen.

\section{The Role of Iran and Turkey}

By reviewing Egypt's present strategic paralysis and Saudi Arabia's fervent path of fueling and propagating sectarianism to sustain the regional status quo (keeping Iran politically alienated and diplomatically crippled), "the fact is for the first time in half a century, Washington lacks a truly consequential Arab partner with whom to cooperate on matters relating to peace and war" (Miller, 2013). In this respect, Washington's regrouping and game-changing for managing regional rivalries, including the more than alarming

\footnotetext{
5 If China is like all previous great powers - including the United States - its definition of "vital" interests will grow as its power increases - and it will try to use its growing muscle to protect an expanding sphere of influence (Walt, 2011 p. 9).
} 
situation in $\operatorname{Iraq}^{6}$ followed by the spillover effects of the Syrian civil war, have indicated a necessity for rebalancing Middle East's security system. To avoid Iraq's disintegration and above all to preserve a regional balance of power which will not be disrupted by Iran's exercise of greater influence in the Middle East and its continued rigid approach on Syria and Lebanon amongst others, the US has to examine the case of coordinating a different set of alliances. Hence, in an effort to secure its greater Middle East geopolitical strategy, the US administration has been revisiting long-lasting polarized misperceptions next to the pragmatic recognition of aligning interests. By reviewing "special relationships" (i.e. Saudi Arabia, Egypt, and Israel) and restoring channels of cooperation along with providing security guarantees and setting action limits (i.e. Iran, Turkey, and member states of Gulf Cooperation Council), the Americans have been testing working patterns so as to better serve the interests of their medium term grand strategy for the region.

What's more, during Obama's second term of office, US geopolitical planning has introduced the active engagement of two non-Arab Muslim countries which are listed along with Israel as the most influential powers in the region to represent the leading strategic schism between Shia and Sunnis, namely Shiite Iran and Sunni Turkey ${ }^{7}$. Engaging Iran in a constructive and mutually beneficial process of rapprochement would result, if successful, in American recognition of fundamental security concerns in the region and vice versa. This is the core challenge facing all the parties and its resolution will transform relations not only between Iran and the West, but also among antagonists throughout the region. The battlefields in Syria and Iraq are actually being portrayed as the ultimate test case for paving the way towards progressively establishing the new balance of power.

In light of the above, by choosing two historical and strategic rivals as the principal agents for assuming elevated roles in the region, the US has been setting forward a strategy of balancing and containment (using each to check the other) that does not entail Washington's direct engagement and allows itself to decrease its regional footprint. By acting as an offshore balancer, the US can take advantage of the opportunities to play off the two rivals (Turkey and Iran) against one another (Layne, 1998, p. 21) "by letting them compete and balance against, and contain, each other" (Layne, 1997, p. 119). Taking into account competing interests and geopolitical rivalries among Ankara and Tehran for expanding their regional influence, the stiff arenas in Iraq and Syria serve as an example of managing "buffer zones-states" in order to avoid an uncontrolled escalation of regional rivalry that will draw all competing state-actors (including Saudi Arabia) into a direct confrontation. Essentially, buffer zones make up an integral part of how the pattern of balance of power politics progressively evolves and works in practice. One should also note Russia's consent over the above mentioned shift of strategy pursued by the Obama administration. By offering its "good offices" and contributing as a broker in the mediation process between Iran and the international community, in a form of a trade-off with the US,

\footnotetext{
${ }^{6}$ In the case of Iraq's strategic failure and course of "slow death", one of the key failings and the "principle results of the 2003 US invasion of Iraq was that it released the Shiite genie out of the Middle East bottle" and paved the way for Iran steadily becoming one of the major strategic beneficiaries of the US occupation of Iraq. By reducing Iraq's power and by allowing the Shia to become the dominant political force in Iraq, the US removed the main country balancing Iran. What is more, Tehran sieged the day for filling a power vacuum and has wisely exploited an opportunity for asserting its role and expanding its regional influence, including the use of its sectarian card (it should be noted that Iran's main concern is to establish strategic and not sectarian alliances). In addition, the Syrian civil has provided a great boost for expanding "sub systemic attempts by each of the region's two main blocs -the US-led Sunni camp, incorporating the Arab Gulf, and the Iranian-led, predominantly Shii, so-called “rejectionist faction' supported by Iraq and Hezbollah- to improve its position at its rival's expense22" (Ifantis, 2013; Walt, 2013). 7 Regarding the rationale of the US administration, Turkey's soft-power model to fill the void left by Egypt and occupy itself as the vanguard of moderate Sunni Islam in the region has been linked to the aforementioned US strategic interests in the greater Middle East.
} 
Russia has been granted the right to maintain its sphere of influence in Syria but also to avoid pushing forward an anti-hegemon agreement with Tehran that would challenge the evolving regional order in the Middle East (the deployment of Russian ground troops in the Syrian conflict serves as conclusive evidence of a new "Yalta Agreement" for the Middle East).

Furthermore, by establishing a buffer zone in the Syrian territory to avoid a direct confrontation, the growing competition between all parties involved allows the Americans to set up a system of checks and balances to both elevate and limit Turkey's and Iran's diverging strategies (with special emphasis placed on the sectarian conflict between the Shia and Sunni, the prominent role of energy resources-energy security, vulnerabilities of the Kurdish issue and the interplay between all three $)^{8}$. More importantly, from a US perspective, such a strategy handles provisions for both Turkey and Iran to regularly check and balance over each other while preventing both from becoming too powerful and challenge the evolution of the "under-construction" regional balance of power. As Walt (2013) points out, "if you are playing the balance of power game, you want to maximize your diplomatic flexibility and avoid becoming overly committed to any particular ally". If the balance of power strategy proves to be a successful one, the short-term instability in Syria would have to be evaluated as the necessary prerequisite for successively developing a more secure and stable Middle-East.

Among the pitfalls involved, one has to note that parallel to the conclusion of negotiations between Washington and Tehran for recognizing security concerns on either side and finalize respective spheres of influence, it remains uncertain how and through the use of which policy instruments Iran will exercise its leverage in the region. As the risk of an accident always lurks, one should bear in mind that the US unfolds its policy in a remote context. On top of that, as far as Turkey weak link of leading Sunni Islam is concerned, closing the capability-expectations gap reveals a major risk factor and a central strategic hurdle for the American security-establishment. After all, implementation of the new Turkish statecraft requires efficient adjustment of former PM Davutoğlu's "rhythmic diplomacy" to the needs of the region's new geopolitical choreography provided by the USA reality reaffirming both Turkey's rising anxiety over the process of unlocking Iran's reintegration in the international community which should shed more light of pragmatism on its foreign policy behavior alongside Ankara's strategic inexperience to dig its heels in the region's "deep waters". Turning from foreign affairs to Turkey's increasingly polarized political environment of a deteriorating "illiberal democracy" where the President of the Republic has cemented its role as the sole arbiter for all major political decisions, the fact that "most policymaking seems to hinge on Erdoğan's ideas" (Dempsey, 2016a; 2016b) and his troubling misperceptions, have already caused tangible risks for Turkey's domestic and foreign policy affairs.

For the time being, the Americans are already in a position to evaluate Turkey's performance and assess the Turkish President's handicapped and alarmingly short-sighted worldview. Furthermore, the US administration has come to acknowledge that Ankara was in need for a few years of previous work experience before meeting the strategic demands of such promising job description drafted by the Obama administration. On the other hand, recent tensions between Turkey and Russia further increase Washington's leverage over Ankara (including Ankara's approval of a larger standing naval presence in the Black Sea to deter Russia's growing assertiveness) and pave the way for possible adjustment of Turkish foreign policy in the strategic

\footnotetext{
${ }^{8}$ When it comes to the unprecedented (following WWII) refugee crisis, one has to acknowledge that it is the product of Syria's buffer-zone status.
} 
framework set by the US over the Middle East (indicative examples have included apart from Turkey's "decision to cancel the Chinese missile deal, explore reconciliation with Israel, aligning with the Gulf's Sunni monarchies, improve cooperation with NATO, work more closely with the US over Syria and Iraq") (Kirişci, 2016); a development allowing over time Turkey’s prominent role in managing war-torn Syria.

All in all, "it is correct to see Turkey as a critical partner in crisis management for the EU and NATO, but the reality goes well beyond this immediate image. The conflict and competition in Turkey's neighborhood are unlikely to be transient and may prove very durable, presenting Ankara and transatlantic partners with long-term, structural challenges, from migration to terrorism, alongside more conventional threats" (Lesser, 2016). As the Americans set global imperatives with regional applications, of utmost importance will be the search between Turkey and the US for a balance among strategic objectives and tactical commands for the future of Eastern Mediterranean and the Middle East; a more than challenging mission for the next US President that will take office in January 2017. For the time being it seems like the relationship between Turkey and the West will be driven by security-heavy transactional interests, rather than shared common values. In the end of the day, as long as Turkey does not attempt to bite off more that it can chew, by applying forward thinking and policy planning under the highest bid for a "Turkey central-power scenario", mismatch between capacities and ambitions will be kept to a minimum.

\section{Turkey and the Syrian Refugee Crisis}

It has already being stressed that the strategic environment Turkey faces is increasingly wide, complex, and characterized by a range of hard and soft security issues, many of which cut across regional lines. By setting as the benchmark of Turkish foreign policy, the effort to become a main player and long-term actor in the Middle East, at the first phase of Syrian refugee crisis the Turkish government adopted an "open door policy". By applying soft power instruments of "humanitarian diplomacy" (Khan, 2015, pp. 45-47; Hussain \& Hussain, 2015, pp. 47-50), the Turkish government perceived the Syrian conflict as a strategic opportunity to be the actor "establishing the order" in the Middle East, pursue its regional mediator status and contribute to the solution of humanitarian crises in Muslim countries. Later on, due to tactical mistakes in the conduct of its foreign policy (including Turkey's reluctant role to actively engage in the fight against ISIS/Daesh in order to avoid strengthening the Syrian Kurds alongside the spill over effect of such a policy in the domestic front of its Kurdist separatist movement) coupled with the dramatic increase in the numbers of refuges crossing the border, Turkey (re)turned to a "non-arrival" policy calling for international aid with a specific emphasis on burden-share and the need for "safe heaven" and "no-fly zone" (Ayman, 2014, p. 22). At bottom, the case of Turkey demonstrates the linkages between international and domestic politics as well as the nexus between foreign and asylum policy. Furthermore, the Syrian civil war and refugee crisis "has crystallized not only the limitations of Turkey's aspiration to be a normative power in the Middle East but also some of the dramatic changes in style and substance of Turkish foreign policy under the Justice and Development Party (AKP) governments" (Oktav \& Çelikaksoy, 2015, p. 417). However, as of June 2016, following previous section's analysis and the expected realignment with the US policy, there are initial signs indicating Turkey's shifting policy on Syria with the emphasis being placed on cold-heartedly accepting a distinct politico-military role for the Democratic Party of Syria (PYD) and its armed wing (YPG) which continues to serve as the leading actor on the ground in the fight against ISIS/Daesh. 


\section{Conclusions and Recommendations}

In an era of lacking leadership in Europe, the refugee crisis compels Europeans to face a number of inconvenient truths and misguided perceptions. The EU's southern security challenges are extraordinary complex in both form and force, with external and internal dimensions of utmost importance for the EU. Unfortunately, as a result of conflicting national interests and relevant narrow minded state-centric perspectives, EU initiatives continue to display a lack of political commitment. Intergovernmental competitive bargaining, resulting in collective decisions taken at the lowest common denominator, has prevailed. Taking into account the linkage between the multi-level management of migration and refugee flows, the rising movement of jihadist fighters and the alarming threat of radicalization, the EU needs to a solid and adequately comprehensive long-term approach to deal with these challenges. The authors note that, "no common European asylum and refugee policy can be expected until Europe's borders are adequately managed and the number of migrants reaching its shores falls. Europe's borders can be secured only through a concentric (security) circles approach: outside Europe, at Europe's borders themselves and within Europe's borders" (Garavoglia, 2016).

On a larger scale, as presented in the previous section, the conflicts driving today's refugee crisis are symptomatic of the shifting structure of international system that has been developed over the past 70 years. Noting that, the Syrian refugee crisis cannot be resolved without referring to the wider context of global governance, including the active and coordinated involvement of the five permanent members of the UN's Security Council. The most important and long-term chance of the international and European policy tackling migratory flows, remains dealing with the refugee crisis on its sources. Without resolving the major crises and conflicts in the Middle East and North Africa, one cannot expect to handle the refugee crisis and the migratory flows (Yazgan, Utku, \& Sirkeci, 2015, p. 184). In this context, the international community, along with any necessary military actions in order to ultimately crush ISIS/Daesh should be committed to a series of medium-and long-term policies for the democratization of the Middle East based on the universal values of freedom, equality and human rights. As such, this value system is not merely about Western norms; instead, its validity extends much further and serves as the absolute custodian for a more humane and open society, regardless of religious beliefs and cultural traditions.

The Syrian refugees flows is crucial, as "the European Union and Europe as a continent have not been called to face a refugee crisis of this size since the end of the World Word II", as well as "this crisis brought to the forefront the limited mechanisms and responses in place to meet needs in place, the absence of a truly common European asylum space and the flaws of the Dublin Regulation" (Dimitriadi, 2015). Europe is today at a crossroads; between a continent separated by borders and ethnocentric egos, and a continent which strives to find regional solutions to global problems. Sooner or later, it will become clear that an effective refugee crisis management requires a series of short and long-term measures on the basis of interrelated responsibility and solidarity (Tsourdi \& De Bruycker, 2015). On the 6th of April the European Commission set out steps to be taken towards a more fair and efficient European Asylum System. The Commission suggests that there is a need for applying a new system for allocating asylum applications in the EU based on a distribution key reflecting the relative size, wealth and absorption capacities of the Member States; a genuine common EU asylum system by transforming the current Asylum Procedures Directive into a new Regulation, establishing a single common asylum procedure in the EU, as well as by replacing the current Qualification Directive by a Regulation, setting uniform rules on the procedures and rights to be offered to beneficiaries of international 
protection; a stronger mandate for EASO so that it can play a new policy-implementing role and a strengthened operational role.

To cut a long story short, the EU's inconvenient truth is that during the last six years the stakes involved for the European integration project have seriously increased, thereby introducing a new geometry of state relations that will continue altering the balance of power among key EU regional groupings (Germany, France, Central and Eastern Europe, Europe's south). As a result of the three crises (sovereign debt, Ukraine, refugees) and the expected UK's withdrawal from the EU, a more fragmented Europe will have a harder time providing security at a time when greater cohesion and activism are needed to cope with threats in the Mediterranean basin and the Middle East.

In essence, with the US acting as a pragmatic and flexible offshore balancer which shifts burdens worldwide, Europe must step up and face "its inability to influence geopolitical developments in and around Syria, the prospect of greater migration flows and the EU's limited capacity or willingness for absorption, and the EU's inadequate ability to efficiently protect its external borders"'. By 2017, it should establish the long needed basic framework for kicking-off a thorough and meaningful common asylum and refugee policy. It must also reach a political agreement to make use of its own resources in order to effectively protect its external borders. This will require provisions for setting up a brand new European Border and Coast Guard, as well as creative burden sharing with $\mathrm{NATO}^{10}$. In this respect, the EU will have to redirect its financial, organizational and political support to the countries which are the first to be exposed, namely Greece and Italy. Simultaneously, when it comes to relocations, the European Commission should direct its resources to develop a medium-term funding mechanism for Member States that are willing to offer sanctuary.

The above mentioned developments would introduce true partnership and risk-sharing between the member-states of the EU It is the most feasible way to reverse the damaging effects of rising Euro-skepticism, autocratic populism, and poisonous nationalism that will irrevocably shape the course of European integration. It will lessen human suffering and strengthen the EU's positive outlook. In conclusion, in an era when the need for increased policy coordination between the power centers of a multi-polar world becomes more than evident, Europe needs an alignment of its internal and external policies more than ever before.

\section{References}

Amnesty International. (2016). EU Turkey Summit: EU and Turkish leaders deal death blow to the right to seek asylum. Retrieved from https://www.amnesty.org/en/latest/news/2016/03/eu-turkey-summit-reaction/

Aras, N. E. G., \& Mencutek, Z. S. (2015). The international migration and foreign policy nexus: The case of Syrian refugee crisis and Turkey. Migration Letters, 12(3), 193-208.

Ayman, S. G. (2014). Turkey and Iran: Between friendly competition and fierce rivalry. Arab Studies Quarterly, 36(1), 6-26.

Baxevanis, C., \& Papadaki, M. (2014). EU asylum policies \& the Greek presidency: An EU opportunity. Hellenic Studies/Etudes Helleniques, 22(1), 107-120.

BBC. (2015). Migrant crisis: Three million expected to reach EU by 2017 . Retrieved from http://www.bbc.com/news/world-europe-34732415

\footnotetext{
9 All of the above shortcomings coincided with strong Euro skeptic, xenophobic, and Islam phobic sentiments in several of the EU's member-states (Dempsey, 2016).

${ }^{10}$ In particular, regarding Standing NATO Maritime Group2 which has been deployed to the Aegean Sea, "its assets should be returned to NATO's "core business"- namely, Operation Active Endeavor in the Mediterranean Sea and Operation Ocean Shield off the Horn of Africa - as soon as the surge in arrivals on Greek shores abates. Then, the navy component of a European Border and Coast Guard (EBCG) should take over its duties. Although deploying such missions to the central Mediterranean and eastern Mediterranean is a matter for the European Council to take up, their operationalization should be left to the EBCG, which should control its own resources independently from the member states" (Garavoglia, 2016).
} 
BBC. (2016). Migrant crisis: Migration to Europe explained in seven charts. Retrieved from http://www.bbc.com/news/world-europe-34131911

Berti, B. (2015). The Syrian refugee crisis: Regional and human security implications. Strategic Assessment, 17(4), 41-53.

Brookings Institution. (2012). The West and Turkey: Their role in shaping a wider global architecture. Proceedings of The 2012 $\begin{array}{llllll}\text { SakipSabanci Discussion } & \text { with } & \text { Zbigniew } & \text { Brzezinski. } & \text { R. }\end{array}$ fromhttp://www.brookings.edu/ /media/events/2012/5/02-turkey-west/20120502_turkey_west.pdf

Brooks, S. G., Ikenberry, G. J., \& Wohlforth, W. C. (2013). Lean forward: In defense of American engagement. Foreign Affairs, 92(1), 130-142.

Collet, E. (2016). The paradox of the EU-Turkey refugee deal. Migration Policy Institute. Retrieved from http://www.migrationpolicy.org/news/paradox-eu-turkey-refugee-deal

Dempsey, J (2016a). Judy asks: Is Erdoğande stroying Turkey? Judy Dempsey's Strategic Europe—Carnegie Europe. Retrieved from http://carnegieeurope.eu/strategiceurope/?fa $=62938$

Dempsey, J. (2016b). Judy asks: Is Europe turning its back on refugees? Judy Dempsey's Strategic Europe-Carnegie Europe. Retrieved from http://carnegieeurope.eu/strategiceurope/?fa=63251

Dimitriadi, A. (2015). Europe's dubious response to the refugee crisis. ELIAMEP Thesis, 1, 1-8. Retrieved from http://www.eliamep.gr/wp-content/uploads/2015/09/ELIAMEP-Thesis-1-2015_Ang.Dimitriadi.pdf

Euroactic.com. (2016). Bulgaria fears becoming alternative route for refugees. Retrieved fromhttps://www.euractiv.com/section/justice-home-affairs/news/bulgaria-fears-becoming-alternative-route-for-refugees/

European Union: European Commission, Communication from the Commission to the European Parliament, the European Council and the Council: Second Report on relocation and resettlement, 12 April 2016, COM(2016) 222 final.

European Union: European Commission, Communication from the Commission to the European Parliament, the European Council and the Council: First Report on the progress made in the implementation of the EU-Turkey Statement, 20 April 2016,COM(2016) 231 final.

European Union: European Commission, Communication from the Commission to the European Parliament, the Council, the European Economic and Social Committee and the Committee of the Regions. A European Agenda on Migration, 13 May 2015, $\operatorname{COM}(2015) 240$ final.

European Council on Refugees and Exiles (ECRE), Forum Réfugiés-Cosi, the Irish Refugee Council and the Hungarian Helsinki Committee. (2014). Annual Report 2013/2014, Retrieved from http://www.asylumineurope.org/sites/default/files/shadow-reports/aida_annual_report_2013-2014_0.pdf

Frontex. (2015). Annual risk 2015 analysis $\quad$ Retrieved from http://frontex.europa.eu/assets/Publications/Risk_Analysis/Annual_Risk_Analysis_2015.pdf

Garavoglia, M. (2016), Securing Europe's borders: The first step to a comprehensive asylum policy. Brookings Institution. Retrieved from http://www.brookings.edu/blogs/order-from-chaos/posts/2016/05/02-securings-europes-borders-garavoglia

Hussain, N., \& Hussain, A. (2015). Turkey's role in the changing Middle Eastern dynamics: challenges and prospects. Journal of European Studies, 31(2), 42-54.

Ikenberry, G. J. (2011). The future of the liberal world order: internationalism after America. Foreign Affairs, 90(3), 56-68.

Ifantis, K. (2013). The US and Turkey in the fog of regional uncertainty. Hellenic Observatory Papers on Greece and Southeast Europe. GreeSE Paper, 73, 1-40.

IOM (2016). Migrant arrivals in Europe in 2016 top 55,000, over 200 deaths. Retrieved from https://www.iom.int/news/migrant-arrivals-europe-2016-top-55000-over-200-deaths

Khan, M. S. (2015). The transformation of Turkish foreign policy in the Middle East. Policy Perspectives, 12(1), 31-50.

Kirişci, K. (2016). New year, new leaf? What to watch in Turkey in 2016. Brookings Institution. Retrieved from http://www.brookings.edu/blogs/order-from-chaos/posts/2016/01/04-what-to-watch-in-turkey-in-2016-kirisci

Lesser, I. O. (2016). Turkey's travails, transatlantic consequences: Reflections on a recent visit. GMF on Turkey. Retrieved from http://www.gmfus.org/publications/turkeys-travails

Layne, C. (1998). Rethinking American grand strategy: Hegemony or balance of power in the twenty-first century? World Policy Journal, 15(2), 8-28.

Layne, C. (1997). From preponderance to offshore balancing: America's future grand strategy. International Security, 22(1), 86-124.

Lehne, S. (2016). How the refugee crisis will reshape the EU. Carnegie Europe. Retrieved from http://carnegieeurope.eu/2016/02/04/how-refugee-crisis-will-reshape-eu/itj7 
Miller, A. D. (2013). The shrinking: Why the Middle East is less and less important for the United States. Foreign Policy. Retrieved from http://www.foreignpolicy.com/articles/2013/10/17/the_shrinking_does_the_middle_east_matter

Niblett, R. (2012). A tough second term for Obama on foreign policy. Chatam House. Retrieved from https://www.chathamhouse.org/media/comment/view/187059

Nomikos, J. M. (2013). Combating illegal immigration, terrorism, and organized crime in Greece and Italy. International Journal of Intelligence and Counterintelligence, 26(2), 288-303.

Oktav, Ö. Z., \& Çelikaksoy, A. (2015). The Syrian refugee challenge and Turkey's quest for normative power in the Middle East. International Journal: Canada's Journal of Global Policy Analysis, 70(3), 408-420.

Ostrand, N. (2015). The Syrian refugee crisis: A comparison of responses by Germany, Sweden, the United Kingdom, and the United States. Journal on Migration and Human Security, 3(3), 255-279.

Schwarz, B., \& Layne, C. (2002). A new grand strategy. Atlantic Monthly, 289(1), 36-42.

Snyder, J. (1990). Chain gangs and passed bucks: Predicting alliance patterns in. International Organization, 44(2), $137-168$.

Syrigos, A. M. (2016). 5+1 elements interms of migration, Kathimerini. Retrieved from http://www.kathimerini.gr/852917/article/epikairothta/politikh/51-nea-dedomena-gia-to-metanasteytiko

The Economist. (2016). Why the EU-Turkey deal is controversial. Retrieved from http://www.economist.com/blogs/economist-explains/2016/04/economist-explains-5

Tsourdi, E. L., \& De Bruycker, P. (2015). EU asylum policy: In search of solidarity and access to protection. Migration Policy Center, European University Institute, 6, 1-12. $\quad$ Retrieved from http://cadmus.eui.eu/bitstream/handle/1814/35742/MPC_PB_2015_06.pdf?sequence=1

UNHCR. (2014). Asylum trends 2013: Levels and trends in industrialized countries. Retrieved from http://www.unhcr.org/statistics/unhcrstats/5329b15a9/asylum-levels-trends-industrialized-countries-2013.html

Walt, S. M. (2005). The relationship between theory and policy in international relations. Annu. Rev. Polit. Sci., 8, 23-48.

Walt, S. M. (2006). Taming American power: The global response to US primacy. WW Norton \& Company.

Walt, S. M. (2011). The end of the American era. The National Interest, 116, 6-16.

Walt, S. M. (2013). Playing hard to get in the Middle East. Foreign Policy. Retrieved from http://walt.foreignpolicy.com/blog/2072

Walt, S. M. (2013). Conversations: Ten years after the Iraq invasion. The European. Retrieved from http://www.theeuropean-magazine.com/stephen-walt--3/6617-ten-years-after-the-iraq-invasion

Yazgan, P., Utku, D. E., \& Sirkeci, I. (2015). Syrian crisis and migration. Migration Letters, 12(3), 181-192. 